\title{
Studi Literatur: Peran Caregiver Untuk Peningkatan Perawatan Kesehatan Pada Pasien Demensia
}

\author{
Riskha Dora Candra Dewi ${ }^{1 *}$, Kushariyadi ${ }^{2}$ \\ ${ }^{1}$ Politeknik Negeri Jember, riskhadora@polije.ac.id \\ 2Fakultas Keperawatan Universitas Jember, kushariyadi@unej.ac.id
}

\begin{abstract}
ABSTRAK
Peran caregiver terhadap pasien demensia untuk meningkatkan perawatan kesehatan masih belum maksimal. Perawatan pasien demensia merupakan upaya berbasis pengalaman bagi pasien demensia yang kompleks yang dapat meningkatkan tekanan psikologis caregiver. Tujuan penelitian untuk mengetahui keefektifan peran caregiver terhadap pasien demensia untuk meningkatkan perawatan kesehatan. Strategi pencarian studi berbahasa Inggris yang relevan dengan topik dilakukan dengan menggunakan database ScienceDirect, SagePub, Springer dibatasi dari tahun 2014 sampai 2020. Kata kunci yang digunakan adalah "caregiver", "dementia", "health care", "role". Artikel fulltext direview untuk memilih studi yang sesuai dengan kriteria. Kriteria inklusi dalam review ini adalah: petugas kesehatan yaitu caregiver. Pencarian menggunakan kata kunci di atas dengan database ScienceDirect, SagePub, Springer yang sesuai dengan kriteria inklusi hanya 22 artikel. Penelitian yang ditelaah pada artikel ini menggunakan berbagai macam metode yaitu systematic literature review sebanyak 1 artikel, RCT sebanyak 4 artikel, interview sebanyak 1, qualitative study sebanyak 5 artikel, quasi-experimental study sebanyak 2 artikel, participatory research sebanyak 1 artikel, bootstrapping methods sebanyak 1 artikel, scoping review of published literature sebanyak 1 naskah, quantitative study sebanyak 1, cohort study path analysis sebanyak 1, a survey to clarify the evaluation sebanyak 1, SEM sebanyak 1, standardized protokol sebanyak 1. Penelitian dengan menggunakan tehnik random sebanyak 10 artikel, sedangkan yang menggunakan tehnik non-random sebanyak 12 artikel. Peran caregiver terhadap pasien demensia untuk meningkatkan perawatan kesehatan merupakan upaya berbasis pengalaman efektif dan merupakan kegiatan yang paling tepat untuk pasien lansia dengan demensia. Meningkatkan peran caregiver dengan cara mengubah persepsi caregiver terhadap pandangan yang lebih positif tentang perannya.
\end{abstract}

Kata kunci: caregiver, dementia, health care, role

\section{ABSTRACT}

The role of caregivers for dementia patients to improve health care is not yet optimal. Dementia patient care is an experience-based effort for complex dementia patients that can increase the psychological pressure of caregivers. The aim of the study was to determine the effectiveness of the caregiver's role in dementia patients to improve health care. Search strategies for English-language studies that are relevant to the topic are carried out using the ScienceDirect, SagePub, Springer databases limited from 2014 to 2020. The keywords used are "caregiver", "dementia", "health care", "role". Fulltext articles are reviewed to select studies that fit the criteria. The inclusion criteria in this review are health workers, caregivers. A search using the keywords above with the ScienceDirect, SagePub, Springer database that met the inclusion criteria was only 22 articles. Research examined in this article uses a variety of methods, namely systematic literature review by 1 articles, RCT by 4 articles, interview by 1 articles, qualitative study by 5 articles, quasi-experimental study 2 article, participatory research of 1 article, bootstrapping methods of 1 article, scoping review of published literature by 1 articles, quantitative study by 1 articles, cohort study path analysis by 1, a survey to clarify the evaluation by 1, SEM by 1, standardized protocol by 1. Research using random techniques as much as 10 articles, while those using non-random techniques as many as 12 articles. The role of caregivers for dementia patients to improve health care is an effective experience-based effort and is the most appropriate activity for elderly patients with dementia. Enhance the role of the caregiver by changing the caregiver's perception of a more positive view of his role.

Keywords: caregiver role, dementia, health care

*Korespondensi Author: Riskha Dora Candra Dewi, Politeknik Negeri Jember, riskhadora@polije.ac.id 


\section{PENDAHULUAN}

Permasalahan pada beberapa hasil penelitian mengenai peran caregiver terhadap pasien demensia untuk meningkatkan perawatan kesehatan masih belum maksimal. Perawatan pasien demensia merupakan upaya berbasis pengalaman bagi pasien demensia yang kompleks yang dapat meningkatkan tekanan psikologis caregiver ${ }^{1,2,3,4}$. Perawatan yang diberikan oleh caregiver seperti perawatan fisik misalnya perawatan inkontinensia yang paling tepat untuk pasien demensia masih belum maksimal $^{5}$. Perawatan pasien demensia tersebut berhubungan dengan berbagai masalah dan menjadi beban bagi caregiver ${ }^{4,5}$. Tingkat beban yang dialami oleh caregiver tergantung pada beberapa faktor seperti kesehatan psikologis atau emosional dan morbiditas fisik, kehidupan sosial, etnis dan ekonomi ${ }^{6,7,5}$. Beban merawat pasien dengan demensia dihubungkan dengan gangguan perilaku ${ }^{4}$, dan dihubungkan dengan keputusan oleh penerima perawatan ${ }^{8}$.

Di Swedia prevalensi atau jumlah caregiver yang berperan terhadap perawatan kesehatan pasien demensia sebanyak $60 \%$ masih bekerja dan $40 \%$ sudah pensiun dari total caregiver yaitu $50^{1}$.

Factor penyebab peran caregiver dalam memberikan perawatan kesehatan pada pasien demensia belum maksimal antara lain mayoritas pasien demensia dirawat di rumah oleh anggota keluarga dan tingkat kepedulian dalam komunitas perawatan demensia yang seringkali menjadi beban utama bagi caregiver $^{6,9}$. Dampak peran caregiver dalam memberikan perawatan kesehatan pada pasien demensia yang belum maksimal antara lain penurunan kualitas kesehatan pasien demensia dan perencanaan asuhan pelayanan kesehatan. Beban caregiver yang tinggi dan status kesehatan yang buruk serta perilaku sehat yang rendah ${ }^{8}$. Dampak lainnya yaitu terjadi permasalahan gejala fisik yang buruk, risiko kematian yang tinggi ${ }^{8,10}$.

Salah satu solusi terhadap peran caregiver pada pasien demensia untuk meningkatkan perawatan kesehatan antara lain dengan memberikan dukungan ilmu pengetahuan dan teknologi yang dapat meningkatkan kualitas perawatan kesehatan sehingga pasien demensia terjaga kesehatannya. Di samping itu juga dapat mengurangi tekanan psikologis caregiver dalam memberikan perawatan kesehatan ${ }^{11}$.

\section{METODOLOGI}

Jenis studi literature yaitu literature review. Strategi pencarian studi berbahasa Inggris yang relevan dengan topik dilakukan dengan menggunakan database ScienceDirect, SagePub, Springer dibatasi dari tahun 2014 sampai 2020. Kata kunci yang digunakan adalah "caregiver", "dementia", "health care", "role". Artikel fulltext direview untuk memilih studi yang sesuai dengan kriteria. Kriteria inklusi dalam review ini adalah: petugas kesehatan yaitu caregiver. Pencarian menggunakan kata kunci di atas dengan database ScienceDirect, SagePub, Springer yang sesuai dengan kriteria inklusi hanya 22 artikel. Artikel yang digunakan sebagai sampel selanjutnya diidentifikasi dan disajikan dalam tabel 1 .

\section{HASIL DAN PEMBAHASAN}

Penelitian yang ditelaah pada artikel ini menggunakan berbagai macam metode yaitu Interviews and well-evaluated scales sebanyak 1 artikel, systematic literature review sebanyak 9 artikel, RCT sebanyak 4 artikel, cross sectional study sebanyak 1 artikel, qualitative study sebanyak 2 artikel, a survey to clarify the evaluation sebanyak 1 artikel, descriptive statistics sebanyak 1 artikel, dan Studi analisis sebanyak 1 artikel. Penelitian dengan menggunakan tehnik random sebanyak 3 artikel, sedangkan yang menggunakan tehnik nonrandom sebanyak 16 artikel.

\section{Peran Caregiver Untuk Peningkatan Perawatan Kesehatan}

Caregiver dengan status kesehatan yang rendah dapat meningkatkan beban atau tekanan caregiver dalam memberikan perawatan kesehatan ${ }^{1}$. Peran caregiver yaitu memberikan bantuan perawatan pribadi, menangani permasalahan perilaku dan mengurangi beban 
gejala fisik dan kesehatan yang buruk ${ }^{8,12}$, dan mengatasi risiko kematian ${ }^{13}$. Keluarga yang berperan sebagai caregiver menggunakan resep pengobatan dan layanan kesehatan ${ }^{14,15}$.

Penelitian terhadap caregiver yang merawat lansia disabilitas bahwa caregiver menggunakan coping ketika mengalami peristiwa yang membuat stres $^{16}$. Keluarga yang berperan sebagai caregiver lebih sering mempraktikkan bentuk-bentuk koping praktis yang meningkatkan kesehatan fisik yang lebih baik, lebih sedikit beban dan tingkat kesejahteraan yang lebih tinggi ${ }^{17}$.

Keluarga yang berperan sebagai caregiver berperan penting dalam merawat pasien dengan demensia ${ }^{16}$.

Peran caregiver pada perawatan formal yaitu sebagai fasilitator dengan pemerintah untuk menyediakan dan membiayai serta membentuk sistem penjaminan pensiun yang membuat lansia tidak bergantung pada tunjangan jaminan sosial ${ }^{1}$.

Pelayanan sosial yang disediakan untuk lansia seperti tinggal di lingkungan rumah, memberikan perumahan (panti jompo) dengan dilengkapi pelayanan dan fasilitas perawatan yang memadai. Sehingga lansia dengan berbagai jenis demensia dapat tinggal sampai akhir hayat. Hal tersebut merupakan peran caregiver dalam merawat lansia pada tahap terakhir demensia ${ }^{18}$.

Salah satu peran caregiver adalah mengidentifikasi berbagai alternatif perawatan yang lebih disukai lansia demensia dan pengaturan perawatan formal yang didasarkan pada konsep lingkungan dan pemeliharaan kehidupan sehari-hari yang normal ${ }^{18,19}$, dan jenis akomodasi yang berkembang. Caregiver harus berada di pelayanan selama 24 jam sehari untuk memberikan dukungan, bimbingan, dan bantuan $^{18}$.

Peran cargiver antara lain memberi penilaian dasar yang mencakup komponenkomponen berikut: riwayat medis (seperti latar belakang medis dan obat-obatan saat ini); riwayat gejala; konsekuensi psikososial, sikap terhadap penyakit, efek pada kehidupan sehari-hari dan kualitas hidup pasien, pengalaman kerabat, mobilitas (transfer, berjalan, tingkat keterampilan, bantuan yang dibutuhkan, kesesuaian pakaian, penglihatan, kebersihan pribadi, toilet, fasilitas), keparahan gangguan kognitif, atau gangguan perilaku yang dapat mempengaruhi fisiologi tubuh dan kerja sama dengan bantuan toileting; pemeriksaan fisik dan hasil tes laboratorium ${ }^{20,21}$.

Peran caregiver melalui teknologi berupa berbagai produk atau layanan yang dirancang untuk memungkinkan kemandirian bagi pasien disabilitas dan lansia ${ }^{22}$.

Beberapa bukti peran perawat bahwa pengawasan klinis dapat menyebabkan perawat menjadi sukses ${ }^{23}$. Perawat yang merawat pasien demensia akut bahwa intervensi ini secara signifikan dan positif mengubah persepsi perawat dan caregiver terhadap pandangan yang lebih positif tentang perannya, merasa lebih terkontrol dan perasaan dihargai oleh manajer. Pengalaman positif ini penting dalam memutuskan untuk tetap bekerja di bangsal perawatan demensia ${ }^{24}$.

Melakukan diskusi secara intensif dengan para manajer dan mengikuti program persepsi peningkatan kontrol situasional dan keterampilan koping, dengan pemikiran kritis yang lebih baik dan perspektif yang lebih luas yang mengembangkan kompetensi yang lebih diarahkan pada masa depan. Kompetensi ini merupakan faktor motivasi untuk tetap bekerja dalam manajemen keperawatan ${ }^{25}$.

Pentingnya peran perawat-mentor dalam mempertahankan perubahan budaya kerja yang positif yang ditujukan untuk perawat ${ }^{26}$. Mengidentifikasi peningkatan kepuasan kerja dan sikap terhadap dimensi kerja. Ukuran komitmen karier mengungkapkan tingkat niat yang tinggi ${ }^{27}$.

\section{Implikasi Terhadap Praktik}

Peran caregiver dalam melaksanakan intervensi berorientasi pada kesehatan pasien demensia dengan berbagai faktor risiko, kesehatan yang rendah ${ }^{1}$.

Intervensi keperawatan berbasis bukti seperti perawatan fisik terhadap lansia dengan demensia. Perawatan fisik tersebut berbasis pengalaman efektif dan merupakan kegiatan yang 
paling tepat untuk pasien lansia dengan demensia. Praktik keperawatan yang efektif hanya akan diwujudkan dengan menggunakan beberapa sumber bukti yaitu penelitian, pengalaman klinis, dan pengalaman pasien ${ }^{2}$.

Lingkungan pembelajaran yang ramah keluarga, yang menghargai dan menghormati perawatnya, dengan cara yang sama seperti perawat diharapkan untuk menghargai dan merawat pasien, sangat penting dalam memastikan peran perawat atau caregiver dalam perawatan pasien lansia dengan demensia ${ }^{23}$.

\section{SIMPULAN DAN SARAN}

Peran caregiver terhadap pasien demensia untuk meningkatkan perawatan kesehatan merupakan upaya berbasis pengalaman efektif dan merupakan kegiatan yang paling tepat untuk pasien lansia dengan demensia.

Meningkatkan peran caregiver dengan cara mengubah persepsi caregiver terhadap pandangan yang lebih positif tentang perannya.

\section{UCAPAN TERIMA KASIH}

Terima kasih kami ucapkan kepada Politeknik Negeri Jember dan Fakultas Keperawatan Universitas Jember yang telah mendukung hasil penelitian ini sehingga bermanfaat bagi pengembangan IPTEK dan penerapan di masyarakat.

\section{REFERENSI}

1. Terracciano A, Artese A, Yeh J, LaVonEdgerton, Granville L, Aschwanden D, Luchetti M, Glueckauf RL, Stephan Y, Sutin AR, Katz P. Effectiveness of Powerful Tools for Caregivers on Caregiver Burden and on Care Recipient Behavioral and Psychological Symptoms of Dementia: A Randomized Controlled Trial. Journal of the American Medical Directors Association. 2019;1-7. Available from: http: //www.sciencedirect.com.

2. Sittironnarit G, Emprasertsuk W, Wannasewok K. Quality of life and subjective burden of primary dementia caregivers in Bangkok, Thailand. Asian Journal of Psychiatry. Volume 48February 2020; 1-16.

3. Couture M, Ducharme F, Sasseville M, Bradette
C, Gaudet K. A qualitative systematic review of factors affecting caregivers' decision-making for care setting placements for individuals with dementia. Geriatric Nursing. 2019;1-9.

4. Lee K, Puga F, Pickering CEZ, Masoud SS, White CL. Transitioning into the caregiverrole following a diagnosis of Alzheimer's disease or related dementia: A scoping review. International Journal of Nursing Studies. Volume 96August2019;119-131.

5. Chaouni SB, An-Sofie Smetcoren, Donder LD. Caring for migrant older Moroccans with dementia in Belgium as a complex and dynamic transnational network of informal and professional care: A qualitative study. International Journal of Nursing Studies. Volume 101January. 2020;1-9.

6. Kor PPK, Liu JYW, Chien WT. Effects of a modified mindfulness-based cognitive therapy for family caregivers of people with dementia: A pilot randomized controlled trial. International Journal of Nursing Studies. Volume 98October 2019;107-117.

7. Frank L, Shubeck E, Schicker M, Webb T, Epstein-Lubow G. Contributions of Persons Living With Dementia to Scientific Research Meetings. Results From the National Research Summit on Care, Services, and Supports for Persons With Dementia and Their Caregivers. The American Journal of Geriatric Psychiatry. 2019;1-22.

8. Rong $\mathrm{X}, \mathrm{Wu} \mathrm{F}$, Tang $\mathrm{D}$, Zhao $\mathrm{Y}$, Zhang S. Development of a self-management support program for caregivers of relatives with dementia in Shanghai. Geriatric Nursing. 2019;1-7.

9. Rong $\mathrm{X}, \mathrm{Wu} \mathrm{F}$, Tang $\mathrm{D}$, Zhao $\mathrm{Y}$, Zhang $\mathrm{S}$. Development of a self-management support program for caregivers of relatives with dementia in Shanghai. Geriatric Nursing. 2019;1-7.

10. Liew TM, Tai BC, Yap P, Choon-Huat Koh G. Comparing the Effects of Grief and Burden on Caregiver Depression in Dementia Caregiving: A Longitudinal Path Analysis over 2.5 Years. Journal of the American Medical Directors Association. Volume 20, Issue 8August. 2019;977-983.

11. Smagula SF, Stahl ST, Santini T, Banihashemi L, Zhan L. White Matter Integrity Underlying Depressive Symptoms in Dementia Caregivers. The American Journal of Geriatric Psychiatry. 
2019;1-5.

12. Nwakasi CC, Hayes C, Fulton J, Roberts AR. A pilot qualitative study of dementia perceptions of Nigerian migrant caregivers. International Journal of Africa Nursing Sciences. Volume 10. 2019;167-174.

13. Zhang SY, Wu F, Tang DL, Rong XS, Zhao YX. Pilot testing the caregiver self-management intervention for caregivers of relatives with dementia. Geriatric Nursing. 2019; 1-11.

14. Chan EY, Phang KN, Glass Jr, GF, Wee-Shiong Lim. Crossing, Trudging and Settling: A phenomenological inquiry into lived experience of Asian family caregivers of older persons with dementia. Geriatric Nursing. Volume 40, Issue 5September-October. 2019;502-509.

15. Wang, YN.,Hsu, WC.,Yang, PS.,Yao, G., Shyu, YIL. Caregiving demands, job demands, and health outcomes for employed family caregivers of older adults with dementia: Structural equation modeling. Geriatric Nursing. Volume 39, Issue 6November. 2018;676-682.

16. Tatangelo, G., McCabe, M., Macleod, A., You A. "I just don't focus on my needs." The unmet health needs of partner and offspring caregivers of people with dementia: A qualitative study. International Journal of Nursing Studies. Volume 77January. 2018;8-14.

17. Kunik ME, Stanley MA, Shrestha S, Ramsey D, Amspoker AB. Aggression Prevention Training for Individuals with Dementia and their Caregivers: A Randomized Controlled Trial. The American Journal of Geriatric Psychiatry. 2020;1-30.

18. Tak Y, Song J, Woo H, An J. Realist Review: Understanding Effectiveness of Intervention Programs for Dementia Caregivers. Asian Nursing Research. Volume 13, Issue 1February. 2019;11-19.

19. Ruisoto P, Contador I, Fernández-Calvo B, Serra L, Rivera-Navarro J. Mediating effect of social support on the relationship between resilience and burden in caregivers of people with dementia. Archives of Gerontology and Geriatrics. Volume 86January-February. 2020;1-6.

20. Sloane PD, Mitchell CM, Weisman G, et al. The therapeutic environment screening survey for nursing homes (TESS-NH): an observational instrument for assessing the physical environment of institutional settings for persons with dementia. J Gerontol B Psychol Sci Soc Sci
2002; 57: S69-78.

21. Chenoweth L, King MT, Jeon YH, Brodaty H, Stein-Parbury J, Norman R, Haas M, \& Luscombe G. Caring for Aged Dementia Care Resident Study (CADRES) of person-centred care, dementia-care mapping, and usual care in dementia: a cluster randomised trial. 2009.

22. Winstanley J, \& White E. Clinical supervision: Models, measures and best practice. Nurse Researcher. 2006:10, 7-38.

23. Hallberg IR, \& Norberg A. Strain among nurses and their emotional reactions during one year of systematic clinical supervision combined with the implementation of individualized care in dementia nursing. Journal of Advanced Nursing. 1993:8, 1860-1875.

24. Chenoweth L, Jeon YH, Merlyn T, \& Brodaty H. A systematic review of what factors attract and retain nurses in aged and dementia care. 2010.

25. Boettcher IF, Kemeny B, De Shon RP \& Stevens AB. A system to develop staff behaviours for person-centred care. Alzheimer's Care Quarterly. 2004:5, 188-196.

26. Carson KD \& Bedeian AG. Career commitment: construction of a measure and examination of its psychometric properties. Journal of Vocational Behaviour. 1994:44, 237-262.

27. Eloniemi-Sulkava, U., Saarenheimo, M., MarjaLiisa Laakkonen, Pietila, M., Savikko, N., Kautiainen, H., Tilvis, RS., \& Pitkala, KH. Family Care as Collaboration: Effectiveness of a Multicomponent Support Program for Elderly Couples with Dementia. Randomized Controlled Intervention Study. 2009.

28. Corchado, JM., Bajo, J., de Paz, Y., \& Tapia, DI. Intelligent environment for monitoring Alzheimer patients, agent technology for health care. 2007.

29. de Bruin, S., Oosting, S., Van Der Zijpp, A., Enders-Slegers, MJ., \& Schols, J. The concept of green care farms for older people with dementia. 2010.

30. Schoenmakers, B., Buntinx, F., \& Delepeleire, J. Factors determining the impact of care-giving on caregivers of elderly patients with dementia. A systematic literature review. 2010.

31. Fleming, R., \& Purandare, N. Long-term care for people with dementia: environmental design guidelines. 2010.

32. Gentile, S. Second generation antipsychotics in dementia: beyond safety concerns. A clinical, systematic review of efficacy data from 
randomised controlled trials. 2010.

33. Foust, JB., Vuckovic, N., \& Henriquez, E. Hospital to Home Health Care Transition: Patient, Caregiver, and Clinician Perspectives. 2011.

34. Kanamori, M., Suzuki, M., Yamamoto, K., Kanda, M., Matsui, Y., Kojima, E., Fukawa, H., Sugita, T., \& Oshiro, H. A day care program and evaluation of animal-assisted therapy (AAT) for the elderly with senile dementia. 2014.

35. Laakkonen, ML., Raivio, MM., EloniemiSulkava, U., Saarenheimo, M., Pietila, M., Tilvis, RS., Pitkala, KH. How do elderly spouse care givers of people with Alzheimer disease experience the disclosure of dementia diagnosis and subsequent care?. 2015.

36. Peeters, JM., Beek, APAV., Meerveld, JHCM., Spreeuwenberg, PMM., \& Francke, L. Informal caregivers of persons with dementia, their use of and needs for specific professional support: a survey of the National Dementia Programme. 2010.

37. Slaughter, S., Calkins, M., Eliasziw, M., \& Reimer, M. Measuring Physical and Social Environments in Nursing Homes for People with Middle- to Late-Stage Dementia. 2006.

38. Mausbach, BT., Ancoli-Israel, S., von Känel, R., Patterson, TL., Aschbacher, K., Mills, PJ., Ziegler, MG., Dimsdale, JE., Calleran, S., \& Grant, I. Sleep Disturbance, Norepinephrine, and D Dimer Are All Related in Elderly Caregivers of People With Alzheimer Disease. 2006.

39. Boekhorst, St., Willemse, B., Depla, MFIA., Eefsting JA., \& Pot, AM. Working in group living homes for older people with dementia: the effects on job satisfaction and burnout and the role of job characteristics. 2008.

40. Topo, P. Technology Studies to Meet the Needs of People With Dementia and Their Caregivers: A Literature Review. 2009.

41. Verbeek, H., van Rossum, E., Zwakhalen, SMG., Kempen, GIJM., \& Hamers. JPH. Small, homelike care environments for older people with dementia: a literature review. 2009. 
Table 1. Artikel yang digunakan sebagai sampel

\begin{tabular}{|c|c|c|c|c|c|}
\hline No & Penulis, tahun, judul & Sampel & Metode & Random & $\begin{array}{ll} & \text { Hasil } \\
\end{array}$ \\
\hline 1 & $\begin{array}{l}\text { Terracciano, A., Artese, A., Yeh, } \\
\text { J., LaVonEdgerton.,Granville, L., } \\
\text { Aschwanden, D., Luchetti, M., } \\
\text { Glueckauf, RL., Stephan, Y., }\end{array}$ & 44 & RCT & random & $\begin{array}{l}\text { Intent-to-treat analyses found PTC reduced caregiver burden }(d=-0.48) \text { and depressive symptoms } \\
(d=-0.53) \text {, and increased self-confidence }(d=0.68) \text {, but found no significant benefit for behavioral and } \\
\text { psychological symptoms of dementia in care recipients. PTC was rated highly by participants and } \\
\text { program attrition was low, with } 94 \% \text { of caregivers completing at least } 4 \text { of the } 6 \text { classes. }\end{array}$ \\
\hline
\end{tabular}

Sutin, AR, Katz, P. (2019)

Effectiveness of Powerful Tools

for Caregivers on Caregiver Burden and on Care Recipient Behavioral and Psychological Symptoms of Dementia: A Randomized Controlled Trial.

2 Sittironnarit, G., Emprasertsuk, W., Wannasewok, K. (2020). Quality of life and subjective burden of primary dementiacaregivers in Bangkok, Thailand

3 Couture, M.,Ducharme, 31 F.,Sasseville, M.,Bradette, C., Gaudet, K. (2019). A qualitative systematic review of factors affecting caregivers' decisionmaking for care setting placements for individuals with dementia

4 Rong, X.,Wu, F.,Tang, D.,Zhao, Y., Zhang, S. (2019). Development of a self-management support program for caregivers of relatives with dementia in Shanghai

5 Zhang, SY.,Wu, F.,Tang, 4 DL.,Rong, XS., Zhao, YX. (2019). Pilot testing the caregiver selfmanagement intervention for managennent intervention for caregivers of relatives with dementia

$6 \quad$ Kor, PPK., Liu, JYW., Chien, WT. (2019). Effects of a modified mindfulness-based cognitiv
Forty percent of the participants assessed themselves as having burden. Positive predictive factors of the caregivers' quality of life included high education, income, satisfaction towards psychiatric care and having jobs. Female gender, having financial problems, sickness, long caregiving hours per day, burden from taking care of other dependents, and subjective burden $(\mathrm{p}<0.05)$ were negative predictive factors of dementia caregivers' quality of life.

Choosing a new living environment for a person with dementia includes two main concerns for caregivers: (1) evaluating the current living environment and caregiving arrangements; and (2) evaluating potential living environments. The key factor, that is acceptability, reflects the extent to which a change of living environment is personally and socially perceived as desirable, suitable, as well as decent for all stakeholders.

Tidak Content analysis revealed that the main challenges caregivers faced were a lack of reliable and accessible information about dementia care, frustrations related to communication with the care recipient, disturbances in daily routines, and unfamiliarity with and/or difficulty in balancing the caregiver's own health needs. Access to individualized and reliable instruction and/or group support were the major types of support the participants expected for their self-management. Based on the findings and relevant literature, an illustrated caregiver-education booklet was developed and the intervention strategies were also discussed for the program.

random The results demonstrated a stronger sense of self-efficacy regarding the gathering of information about dementia care in both study groups compared to the baseline data. Caregivers participating in the group sessions reported better health-related quality of life, improved responses to behavioral disturbances, and efficacy in the management of stress than those who received telephone instructions. This study provided some preliminary information regarding ways to improve self-management for the target population in mainland China.

Intervention feasibility was established with a high completion rate of $83 \%$ (completing $\geq 5$ out of the 7 sessions) and a low attrition rate of $11.1 \%$. The duration of the average weekly home-based mindfulness practice of the caregivers was 180 minutes (S.D. $=283.8$ ). The intervention group experienced a

PUSLITBANG Sinergis Asa Professional, Jember 


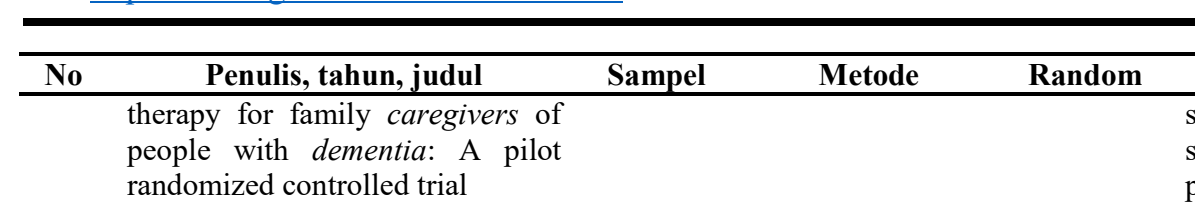

mentia: A pilo

randomized controlled trial

7 Frank, L.,Shubeck, E.,Schicker, 28

participatory

M.Webb, T, Epstein-Lubow, G.

(2019). Contributions of Persons

Living With Dementia to

Scientific Research Meetings.

Results From the National

Research Summit on Care,

Services, and Supports for Persons

With Dementia and Their

Caregivers

8 Chung-Ying Lin, Pei-Yu Shih, Li-

Jung Elizabeth Ku. (2019).

Activities of daily living function and neuropsychiatric symptoms of people with dementia and caregiver burden: The mediating role of caregiving hours

9 Lee, K.,Puga, F.,Pickering, CEZ.,Masoud, SS., White, CL. (2019). Transitioning into the caregiverrole following a diagnosis of Alzheimer's disease or related dementia: A scoping review

10 Chaouni, SB., An-Sofie 31 Smetcoren, Donder, LD. (2020). Caring for migrant older Moroccans with dementia in Belgium as a complex and dynamic transnational network of

participatory
Tidak

Caregiving hours in BADL mediated the relationship of PWDs' BADL function and caregiver burden (effect $=-0.0137,95 \%$ bootstrap $\mathrm{CI}=-0.0379,-0.0003$ ). However, such mediating effects were not found in the relationship of PWDs' neuropsychiatric behaviors and caregiver burden.
Scoping review of random published

literature

qualitative study

Tidak

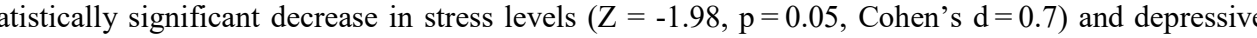
symptoms $(Z=-2.25, p=0.02$, Cohen's $d=0.8)$ at the post-test; and a decrease in stress $(Z=-2.58$, $p=0.01$, Cohen's $d=0.9)$, depressive symptoms $(Z=-2.20, p=0.03$, Cohen's $d=0.7)$, and burden $(Z$ $=2.74, p=0.006$, Cohen's $d=1.0)$, and improved quality of life (physical) $(Z=-1.68, p=0.09$, Cohen's $d=0.6)$ at the 3 -month follow-up compared to the controls. A focus group conducted immediately after the intervention revealed three major themes: Impacts on the family caregivers, Impacts on the people with dementia, and Difficulty in practicing mindfulness.

The PLWD Group influenced the content of the Summit agenda and some Group members were invited to contribute through Summit presentations. The Group influenced Summit outcomes: of the 58 research recommendations that emerged, 30 express ideas contributed by the PLWD.

Twenty-nine studies were organized around three major categories: i) family caregiver experiences on receiving the diagnosis $(n=23)$, ii) needs during this time of transition $(n=18)$, and iii) interventions and outcomes to support their transition into the caregiver role $(n=5)$. While studies may have addressed more than one topic, 16 studies intersected categories of both caregiver experience and needs, and one study intersected categories of needs and interventions. There were several studies that focused more specifically on the caregiver's initial reactions to a diagnosis of Alzheimer's disease or related dementia $(n=9)$, the emotional responses to the diagnosis $(n=14)$, changes in personal relationships and responsibilities with a new role $(\mathrm{n}=16)$. Caregiver needs following the diagnosis included knowledge and information $(\mathrm{n}=14)$, emotional and psychological support $(\mathrm{n}=11)$, and assistance with care planning $(n=7)$. Five papers examined interventions specifically tailored to caregiver needs at this juncture, which support the transition into the caregiver role.

Analyses of the collected data reveal that current dementia care is a challenging, complex and dynamic search process. This process is shaped by (1) multiple factors reflecting the changing care needs of the care recipient during the course of the dementia, (2) the individual (transnational) recourses of the informal caregivers and the (3) current (lack of) accessibility of professional dementia care (driven by the absence of an accessible migration-, culture- and religion-sensitive professional care). The limited professional service-use is predominantly compensated through the search for transnational external 


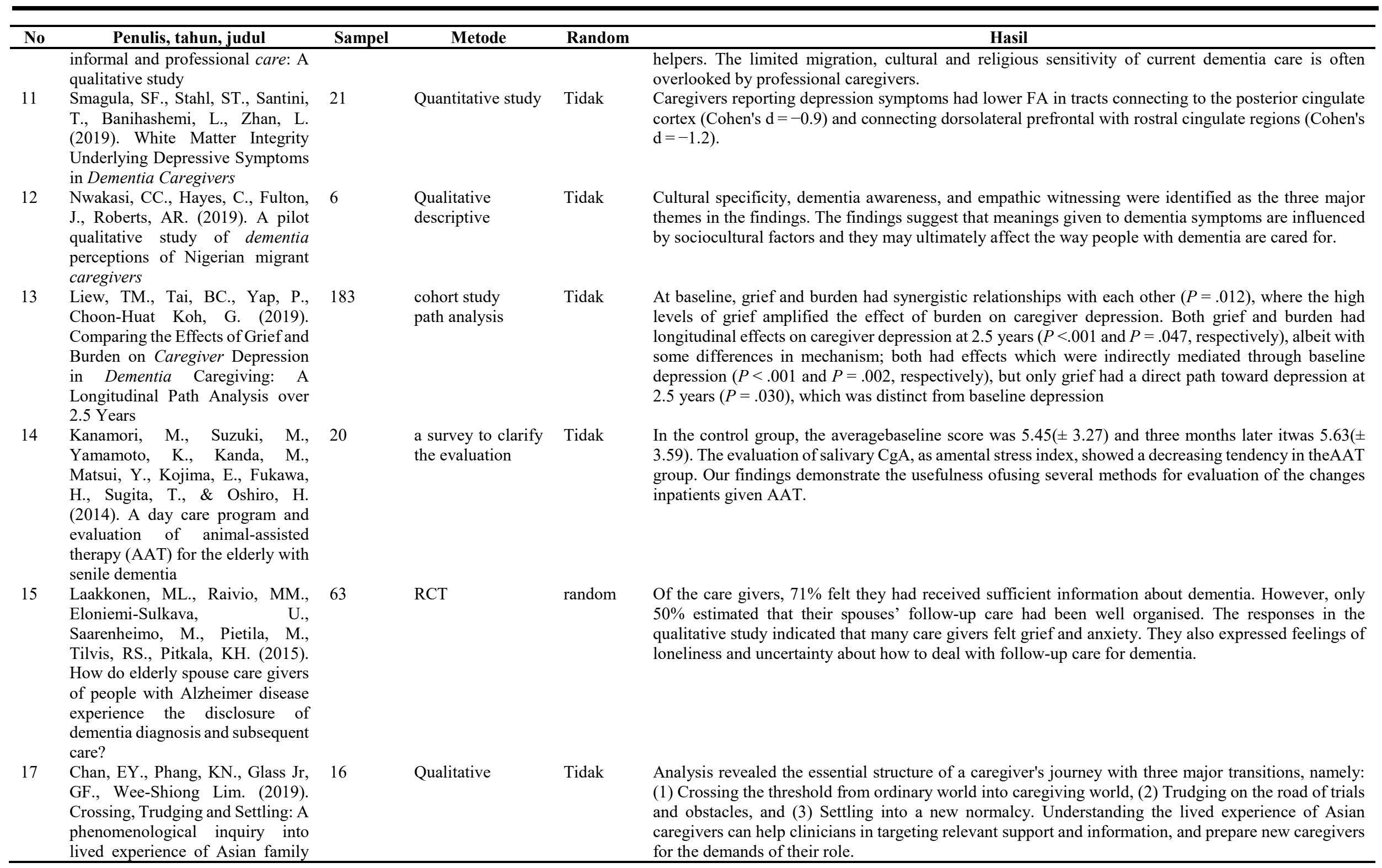

PUSLITBANG Sinergis Asa Professional, Jember 


\begin{tabular}{|c|c|c|c|c|c|}
\hline No & Penulis, tahun, judul & Sampel & Metode & Random & Hasil \\
\hline & $\begin{array}{l}\text { caregivers of older persons with } \\
\text { dementia }\end{array}$ & & & & \\
\hline 18 & $\begin{array}{l}\text { Wang, YN.,Hsu, WC.,Yang, } \\
\text { PS.,Yao, G., Shyu, YIL. (2018). } \\
\text { Caregiving demands, job demands, } \\
\text { and health outcomes for employed } \\
\text { family caregivers of older adults } \\
\text { with dementia: Structural equation } \\
\text { modeling }\end{array}$ & 214 & SEM & random & $\begin{array}{l}\text { Structural equation modeling analyses showed that job demands partially mediated the relationship } \\
\text { between caregiving demands and caregiver health outcomes. The indirect effect of caregiving demands } \\
\text { on caregiver health outcomes through job demands was } 0.208 \text { ( } 95 \% \text { confidence interval: } 0.053-0.335 \text { ). } \\
\text { Nurses should evaluate job demands when screening for high-risk caregiver groups vulnerable to high } \\
\text { caregiving demand. Interventions aimed at lessening both caregiving demands and job demands may } \\
\text { improve caregiver health outcomes for family caregivers of older adults with dementia. }\end{array}$ \\
\hline 19 & $\begin{array}{l}\text { Tatangelo, G., } \\
\text { McCabe, M., Macleod, A., You A. } \\
\text { (2018). "I just don't focus on my } \\
\text { needs." The unmet health needs of } \\
\text { partner and offspring caregivers of } \\
\text { people with dementia: A } \\
\text { qualitative study }\end{array}$ & 24 & Qualitative study & Tidak & $\begin{array}{l}\text { The first theme represents caregivers' overall assessment and perception of their health needs. The } \\
\text { remaining four themes represent the most important aspects of caregivers' health needs; mental health, } \\
\text { emotional support and social relationships, healthy diet and exercise, and personal time. While these } \\
\text { themes were similar for offspring and partner caregivers, the specific needs and barriers within these } \\
\text { areas were different. A prominent barrier for partner caregivers was that they had difficulty in } \\
\text { acknowledging their needs. Despite this, partner caregivers demonstrated unmet emotional support } \\
\text { needs, as they no longer had emotional support from their partner with dementia. They also had an unmet } \\
\text { need for time away from the care-giving role, yet they were reluctant to leave the person with dementia. }\end{array}$ \\
\hline 20 & $\begin{array}{l}\text { Kunik, ME., Stanley, MA., } \\
\text { Shrestha, S., Ramsey, D., } \\
\text { Amspoker, AB. } \quad(2020) \text {. } \\
\text { Aggression Prevention Training } \\
\text { for Individuals with Dementia and } \\
\text { their Caregivers: A Randomized } \\
\text { Controlled Trial }\end{array}$ & 228 & $\mathrm{RCT}$ & random & $\begin{array}{l}\text { Aggression incidence and secondary outcomes did not differ between groups. However, in those } \\
\text { screening positive for IWD depression or caregiver-IWD relationship problems, those receiving EU-PC } \\
\text { had significant increases in depression and significant decreases in quality of the caregiver-IWD } \\
\text { relationship, whereas those receiving APT showed no changes in these outcomes over time. }\end{array}$ \\
\hline 21 & $\begin{array}{l}\text { Tak, Y., Song, J., Woo, H., An, J. } \\
\text { (2019). Realist Review: } \\
\text { Understanding Effectiveness of } \\
\text { Intervention Programs for } \\
\text { Dementia Caregivers }\end{array}$ & 1225 & $\begin{array}{l}\text { quasi- } \\
\text { experimental }\end{array}$ & random & $\begin{array}{l}\text { None of the studies included all the derived contexts while explaining in detail the mechanism of the } \\
\text { intervention effectiveness. Among contexts, the variable of other family members requiring care was } \\
\text { not included in all studies. Among the analyzed studies, no studies have applied repeated intervention. } \\
\text { Most studies included only some variables of context and mechanism, and these variables did not } \\
\text { directly explain the effectiveness of intervention. }\end{array}$ \\
\hline 22 & $\begin{array}{l}\text { Ruisoto, P., Contador, I., } \\
\text { Fernández-Calvo, B., Serra, L., } \\
\text { Rivera-Navarro, J. (2020). } \\
\text { Mediating effect of social support } \\
\text { on the relationship between } \\
\text { resilience and burden in caregivers } \\
\text { of people with dementia }\end{array}$ & 283 & $\begin{array}{l}\text { Standardized } \\
\text { protokol }\end{array}$ & random & $\begin{array}{l}\text { The role of caregiver of PWD was more common in women, reporting significantly higher levels of } \\
\text { burden than men. Resilience and social support accounted for most of the variance in burden. } \\
\text { Furthermore, social support partially mediated the relationship between resilience and burden in } \\
\text { caregivers. }\end{array}$ \\
\hline
\end{tabular}

